\title{
Sustainable Material for Local Road Using Pervious Concrete with Various Aggregates
}

\section{Tri Mulyono ${ }^{1}$ and Anisah ${ }^{2}$}

${ }^{1}$ Technical Faculty, State University of Jakarta, Jakarta, Indonesia
${ }^{2}$ Building Technical Vocational Education Program, Technical Faculty, State University of Jakarta, Jakarta, Indonesia

\section{Abstract}

Pollution of air, water, and soil require millions of years to recoup. Sustainable materials as pervious concrete is an advanced pavement material. Environmental benefits arising from its basic feature - high water-permeability. This paper presented the result of laboratory experimental study that is aimed at testing technically important properties of pervious concrete for different types and sizes aggregate $9.5 \mathrm{~mm}$ to $19 \mathrm{~mm}$ and water-cement ratio (wcr) from 0.27 to 0.34 . The following properties of pervious concrete were tested - compressive strength, unit weight at dry conditions, void in mixed, and permeability. The mix proportions used were local material, with proportion Portland Cement Composite is 350 to $450 \mathrm{~kg} / \mathrm{m}^{3}$. The mixture for the trial used 4.25 for aggregate- cement ratios $(\mathrm{A} / \mathrm{C})$ with proportion $6 \%$ sand, $0.2 \%$ superplasticizer, and $15 \%$ fly-ash. The test results showed a slight difference in compressive strength including types and sizes of aggregate. An analysis statistic requirement test shows that data is normal and uniform. The use of natural aggregate is more porous compared to crushed stone with the range of infiltration rate is $(17-21) \mathrm{mm} / \mathrm{s}$. Density and void in mixed are (2.0-2.15) kg/m $\mathrm{m}^{3}$ and (20-22)\%. Good agreement was reached in 0.30 wcr mixture with and aggregate size that passed through a $12.5 \mathrm{~mm}$ sieve, that was retained at $9.5 \mathrm{~mm}$ and that provided compressive strength are 8-14 MPa for 3 days and (15-22) MPa at 28 days. Its meets the strength requirements for local roads in Indonesia.

Keywords: pervious concrete, compression strength, infiltration rate

\section{Introduction}

the responsibility of the $3 \mathrm{rd}$ ICTVET 2018 Conference Committee.
Thousands of people have been affected by flooding in Indonesia over the last few years. When a major new flood event occurs, many people wonder about the link between the extreme event observed and the global phenomenon of climate change, especially as damage caused by floods has increased significantly in recent decades [1]. Losses due to flooding in humans and property are inevitable. However, as our environment changes, so does the need to become increasingly aware of the problems that surround it a specially increasing soil infiltration [2]. The impact of flooding can 
be reduced by providing sustainable material for local road using pervious concrete pavement.

The hierarchy of roads categorizes roads according to their functions and capacities. The basic hierarchy comprises freeways, arterials, collectors, and local roads. Local road have the lowest speed limit, and carry low volumes of traffic [3, 4]. In some areas, these roads may be paved by conventional concrete pavement with compressive strength range $\left(15 \leq f^{\prime}<20\right) \mathrm{MPa}[5]$. Its prevents the absorption of ground water or decreased infiltration and causes large surface runoff and eventually cause flooding. Its use as a stormwater management tool [6 - 11]. A pavement material that provides a porous medium to facilitate the infiltration of stormwater to the underlayers [12]. Pervious concrete as pervious pavements have normally a somewhat similar structure, consisting of a surface pavement layer, an underlying reservoir layer composed normally of stone aggregates, and usually also a filter layer or fabric installed on the bottom [13, 14]. Pervious concrete is concrete with reduced sand or fines and allows water to drain through it. The environmental advantages, such as reducing tire pavement interaction noise, moderating storm-water runoff, and limiting the pollutants entering groundwater an aggregate storage bed will reduce stormwater runoff volume, rate, and pollutants [15 - 17]. The main important function is ability to transport large volumes of water through its pores to the underlying strata [18 - 21], while serving as a pavement for vehicular and pedestrian traffic or local road. Typically, pervious concrete has a water to cementitious materials ratio (wcr) of 0.35 to 0.45 with a void content of $15 \%$ to $25 \%$.

The mixture are composed of cementitious materials, water, coarse aggregate and sand $5 \%$ to $7 \%$ or no fine aggregates [7, $22-25]$ usually with admixtures. Superplasticizer which permits a high reduction in the water content of a given mix without affecting the consistence, or which increases the slump/flow considerably without affecting the water content; or produces both effects simultaneously [26]. Fly ash has been used in concrete at levels ranging from $15 \%$ to $25 \%$ by mass of the cementitious material component $[27,28]$. Strength required for a particular pavement section design; durability; and porosity to produce the desired permeability and maximize the required maintenance intervals. Porosity of pervious concrete pavement increases the unit weight decreases linearly. A void space that comprises porosity is interconnected and rapidly permeable to water movement and is fundamentally different than entrained air captured in the cement paste. A specific design void typically around $20 \%$ for a control $[20,24]$. Unit weight relationship, compressive strength decreases with increased porosity or permeability, tends to be very low ( $<10 \mathrm{in} . / \mathrm{hr}$ ) below $15 \%$ porosity and increases rapidly above $25 \%$. 
In this article, the aims of this study are to determine the mechanical properties of concrete with various aggregates for local roads; and prove the difference between pervious concrete that used natural coarse aggregate and crushed stone.

\section{Methods, Material, and Equipment}

\subsection{Material}

Portland cement composite (PCC), as per Indonesian National Standard/SNI [29] was used for this investigation. The results of the cement properties are: specific gravity is 3.053 and a unit weight is $1420 \mathrm{~kg} / \mathrm{m}^{3}$; consistency is $29.5 \%$; the initial setting time is 73 minutes and final setting is 455 minutes. A coarse aggregate used in pervious concrete should be clean, hard and from durable [9, 30 - 32].

Test result of clay lumps \& friable particles under ASTM C142/C142M - 17 is $3.77 \%$ and organic impurities test with SNI 2816:2014 (ASTM C40/C4OM-11) is meets in organic plate No. 3. Two types of locally available coarse aggregate were included in the study, crushed stone (limestone) and rounded river gravel or natural aggregate or pea gravel [24]. Their physical properties are given in Table 1. Seive analysis procedure under ASTM C136:2012 for sand and coarse aggregates to gradation analysis. There are three different grades for coarse aggregate; passing through the $19 \mathrm{~mm}$ sieve and retained on the $12.5 \mathrm{~mm}$ sieve, passing through $12.5 \mathrm{~mm}$ sieve and retained on the $9.5 \mathrm{~mm}$ sieve, and passing through the $9.5 \mathrm{~mm}$ sieve and retained on the $4.75 \mathrm{~mm}$ sieve. The proportion of mixed aggregates was $6 \%$ fine aggregate (sand) and $94 \%$ coarse aggregate in this experimental research. The result of the aggregates when combined has been shown in Figure 1 for the natural aggregate and crushed stone. The upper and lower gradation limit for the combined aggregate gradations has been referred to by some scholars [20,24] for pervious concrete. The upper gradation limit of the mixture was too rocky for manual placement techniques and the surface was too open to be classed as having a smooth texture. The lower gradation limit represents an area below which low to zero permeability becomes probable.

The chemical admixtures using Sika ${ }^{\circledR}$ ViscoCrete ${ }^{\circledR 1003-s u p e r p l a s t i c i s e r ~ t e c h n o l o g y ~}$ in this research made up $0.2 \%$ of the cement and were dissolved in part of the mixing water. The dosage of the admixtures was according to EN 206-1, where admixture quantities for low dosages $<0.2 \%$ of the cement are only allowed if they are dissolved in part of the mixing water [26]. Mineral admixture using $15 \%$ fly-ash by cement mass added to mixture $[28,33]$. Result of fly-ash for scanning electron microscopy (SEM) with total 
TABLE 1: Properties of fine and coarse aggregate.

\begin{tabular}{l|l|}
\hline Description & Standard Test \\
\hline Specific gravity & $\begin{array}{l}\text { SNI 1969 and } \\
1970: 2016 \text { (ASTM C127 } \\
\text { and C128-15) }\end{array}$ \\
\hline $\begin{array}{l}\text { Absorption (\%) } \\
\begin{array}{l}\text { Bulk density } \\
\text { (kg/m }{ }^{3} \text { ) }\end{array}\end{array}$ & $\begin{array}{l}\text { SNI 03-4804-1998 } \\
\text { (ASTM C29/29M-17a) }\end{array}$ \\
\hline
\end{tabular}

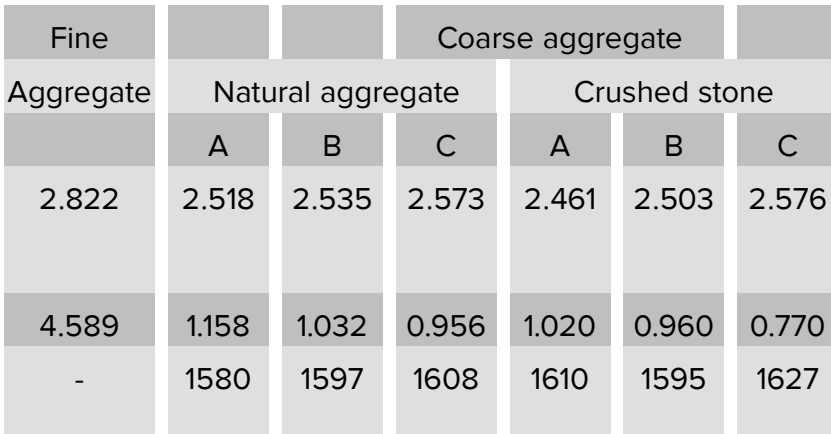

Note: $A$ is passed at $19 \mathrm{~mm}$ and retained $12.5 \mathrm{~mm}$; $B$ is passed at $12.5 \mathrm{~mm}$ and retained $9.5 \mathrm{~mm}$; and C is passed at $9.5 \mathrm{~mm}$ and retained $4.75 \mathrm{~mm}$

$\mathrm{SiO} 2+\mathrm{Al} 2 \mathrm{O} 3+\mathrm{Fe} 2 \mathrm{O} 3=50.57 \%$ included in class $\mathrm{C}$ with minimum requirement of $70 \%$. An average specific gravity test for fly-ash is 2.30. Potable water available in laboratory with the normal pH, conforming to SNI (Indonesia National Standard) requirements, was used for mixing concrete and curing the specimens [34].

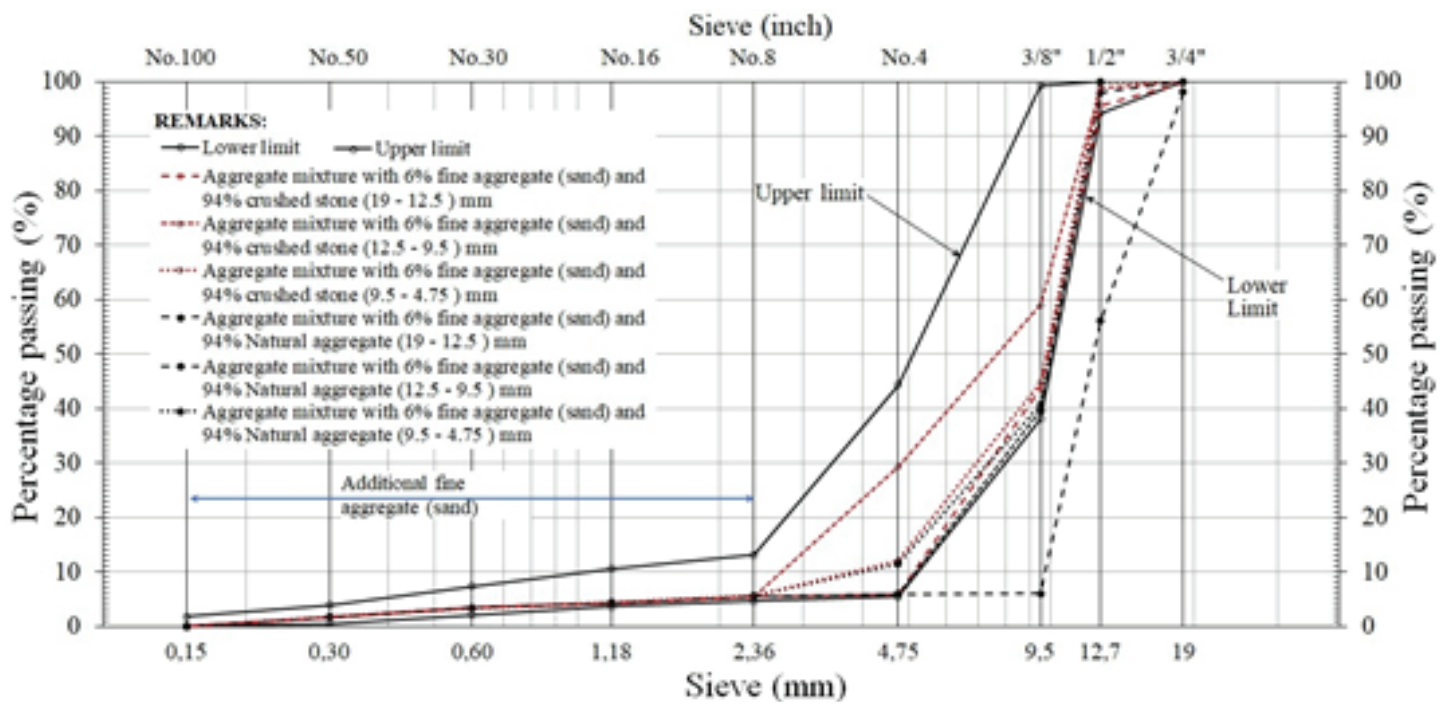

Figure 1: Aggregates combined with crushed stone and natural aggregate of various sizes.

\subsection{Mixture proportion, mixing, casting and compaction}

The local material used in the mixture was a material composition with Portland Cement Composite with a water-cement $(\mathrm{W} / \mathrm{C})$ ratio $0.27,0.3$ and 0.34 , with aggregates of various types and sizes and fly ash and superplasticizer as the added ingredients. The mixture for the trial used 4.25 for the aggregate- cement ratio $(\mathrm{A} / \mathrm{C})$ with a proportion of $6 \%$ for the fine aggregate (sand), $15 \%$ flay-ash and a low dosage of superplastizer [ 9 , 17, 22 - 24]. Proportion material for all ten sets of mixes is shown in Table 2. 
TABLE 2: Previous concrete Mixture for pea gravel and crushed stone with max. Aggregat $19 \mathrm{~mm}, 12.5 \mathrm{~mm}$, $9.5 \mathrm{~mm}$ and $\mathrm{A} / \mathrm{C}$ is 4.25 ( $1 \mathrm{~m}^{3}$ pervious concrete).

\begin{tabular}{|c|c|c|c|}
\hline \multirow[t]{2}{*}{ Material } & \multicolumn{3}{|c|}{ Water Cement Ratio (wcr) } \\
\hline & 0.27 & 0.30 & 0.34 \\
\hline Portland cement composite $(\mathrm{kg})$ & 350 & 400 & 450 \\
\hline Water (litre) & 94.5 & 120 & 153 \\
\hline Coarse aggregate (kg) & 1398.25 & 1598 & 1797.75 \\
\hline Fine aggregate $(\mathrm{kg})$ & 89.25 & 102 & 114.75 \\
\hline Fly-Ash (kg) & 52.5 & 60 & 67.5 \\
\hline Superplasticizer (litre) & 0.7 & 0.8 & 0.9 \\
\hline Total & 1985.2 & 2280.8 & 2583.9 \\
\hline
\end{tabular}

The mixing and casting procedure complied with SNI 7974:2013 [34]. The compaction method is one of the most influential factors in the specimen preparation for previous concrete. Two compaction methods have been assessed [35], in this research, one was using compaction by drop hammer and the other was using of a tamping rod [35, 36]. Although the hammer compaction packed the aggregate particles together more tightly, the density of porous concrete samples increased with the loss of permeability. As the impaction strength of a falling hammer was so strong to crush the weak aggregate and create weak layers, the vibration method seemed to be more suitable for majority of aggregates. However, for the sake of achieving the maximum cohesion between aggregate particles, a combined compaction method was attempted, that was, not only applied the standard rodding compaction method, but also incorporated a drop hummer compactor. This compaction effort allowed most of the coarse aggregate not to deform under compaction whilst increase the contact surface and alignment of aggregate particles, which was believed a substantial aspect to increase the strength [35].

\subsection{Testing}

\subsubsection{Density and void content}

The density and void content of the pervious concrete are calculated based on the measured mass of the consolidated concrete specimen, the volume of the measure, and the total mass of materials batched. The theoretical density is a laboratory determination, and is assumed to remain constant for all batches made using identical component ingredients and proportions [37]. It is calculated with $T=M_{s} / V_{S}$, where, $T$ theoretical density of the concrete computed on an airfree basis, $\mathrm{kg} / \mathrm{m}^{3}, M_{s}$ total mass of all materials batched, $\mathrm{kg}$, and $V_{s}$ sum of the absolute volumes of the component ingredients 
in the batch, $\mathrm{m}^{3}$. Calculate of $V_{s}$ is mass of the concrete in saturated surface density $\left(M_{s s d}\right)$ by subtracting the mass of the concrete in water, $M_{w}$. Density (Unit Weight), $D$ by dividing the net mass of concrete by the volume of the measure, $V_{m}$. Mass of the concrete by subtracting the mass of the measure, $M_{m}$, from the mass of the measure filled with concrete, $M_{c}$. The calculate density unit is is $D=\left(M_{c}-M_{m}\right) / V_{m}$, and void content is a percentage of voids as $U=[(T-D) / T]] 100 \%$. The result of test shown in Table 3.

TABLE 3: Density and void in mixture.

\begin{tabular}{l|c|c|c|c|c|c|} 
& \multicolumn{3}{c|}{ Density (D) kg/m } & \multicolumn{3}{c|}{ Void in mixture (\%) } \\
\hline Types of aggregate & $\begin{array}{c}(19-12.5) \\
\mathrm{mm}\end{array}$ & $\begin{array}{c}(12.5-9.5) \\
\mathrm{mm}\end{array}$ & $\begin{array}{c}(9.5-4.75) \\
\mathrm{mm}\end{array}$ & $\begin{array}{c}(19-12.5) \\
\mathrm{mm}\end{array}$ & $\begin{array}{c}(12.5-9.5) \\
\mathrm{mm}\end{array}$ & $\begin{array}{c}(9.5-4.75) \\
\mathrm{mm}\end{array}$ \\
\hline Natural aggregate & 2.098 & 2.042 & 2.079 & 26.075 & 20.927 & 18.069 \\
\hline Crushed stone & 1.934 & 2.060 & 2.078 & 23.120 & 20.609 & 20.097
\end{tabular}

\subsubsection{Compressive strength and flexural strength}

The cast cylinders were remolded after $24 \mathrm{~h}$, labeled and weighted for testing shown in Figure 2 (a). Then the samples were cured by water [38]. For each batch, two samples were prepared for permeability testing and others were for compression, three tested at 7 days and 28 days, respectively. The results showing up below were all average values were carried out in the laboratory $[39,40]$. Prior to loading process, caps were placed on the ends of samples with sulphur used depended on surface condition of the concrete samples in shown Figure 2 (b).

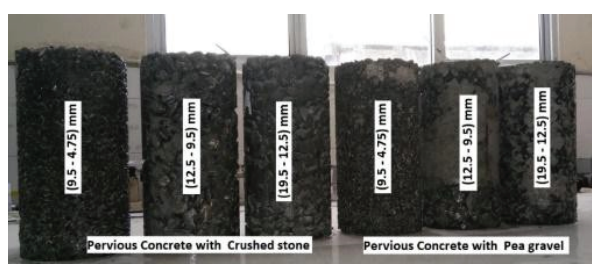

(a)

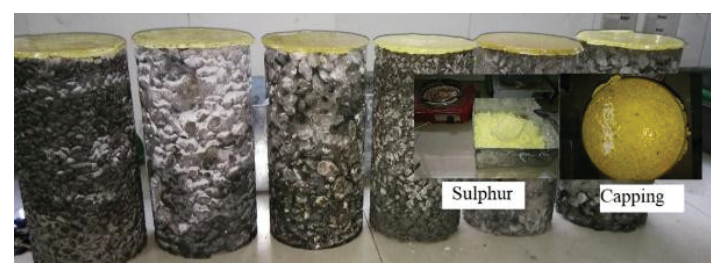

(b)

Figure 2: Sample test (a), Sulphur capping used in samples with rough surface (b).

The compressive strength $\left(f_{C}^{\prime}=P / A\right)$ was conducted in accordance with ASTM C-39 [40], where, $f_{C}^{\prime}$ in MPa, $P$ is maximum compressive force $(\mathrm{N})$, and $A$ is cross-sectional area of the specimen $\left(\mathrm{m}^{2}\right)$. Result of test shown in Table 4. Typical failure specimen test shown in Figure 3. Flexural strength $\left(f_{r}\right)$ in this research was not carried out. Recommended empirical relationships $[41,42]$ is $f_{r}=0.62 \sqrt{f_{C}^{\prime}}$. 
TABLE 4: Average of the compression strength test.

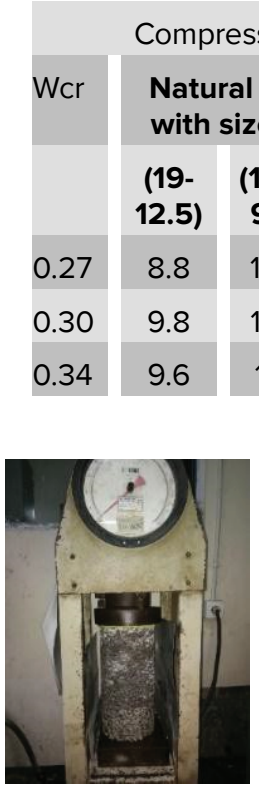

(a)

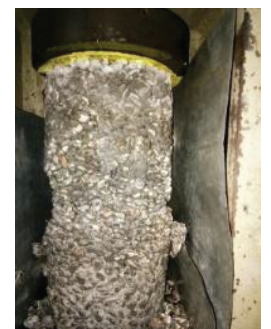

(b)

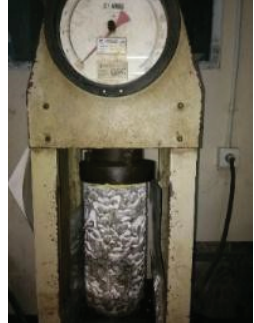

(c)

Compressive strength for 28-days (MPa)

Natural aggregate with sizes of $(\mathrm{mm})$

(19- (12.5- (9.5-

12.5) 9.5) 4.75)

16.8

18.5

22.1

16.3

18.8

21.5

18.7

19.9

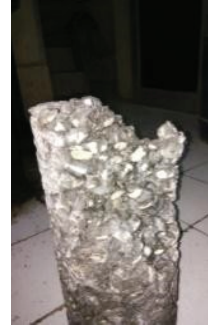

(d)

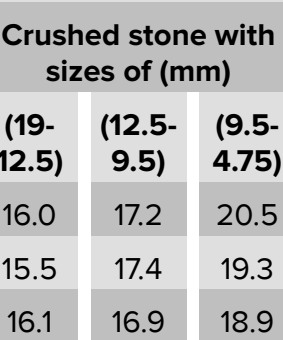

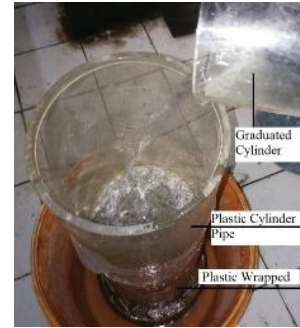

(e)

Figure 3: Compression strength test, sample with $(9.5$ - 4.75) $\mathrm{mm}$ pea gravel (a), typical fracture test specimen at failure for $(9.5$ - 4.75) $\mathrm{mm}$ pea gravel (b), sample with $(19.0$ - 12. 5) $\mathrm{mm}$ pea gravel (c), typical fracture test specimen at failure for $(19.0-12.5) \mathrm{mm}$ pea gravel (d), infiltration test (e).

\subsubsection{Infiltration test}

Infiltration test for water to penetrate through porous concrete was expressed in millimeters per second $(\mathrm{mm} / \mathrm{s})$. Since porous concrete generally owns a much higher permeability compared to the normal dense concrete, the permeability test method for the latter one was not suitable for testing porous concrete [43]. In our research, to determine of infiltration, the cylindrical pervious concrete wrapped in plastic on the circumference was used in this test. With inline duck type, the pipe was tight to inhibit water leakage along the sides of the sample and the top of sample placing a plastic cylinder pipe in Figure 3 (e). The infiltration rate is calculated using $I=K M / D^{2} t$, where $I$ is the surface infiltration rate $(\mathrm{mm} / \mathrm{min}), K=76,394,433.33\left(\mathrm{~mm}^{3} \cdot \mathrm{s} /(\mathrm{kg} \cdot \mathrm{min})\right), M$ is the mass of infiltrated water $(\mathrm{kg}), D$ is the ring's inside diameter $(\mathrm{mm})$, and $t$ is time required for water used in the test to infiltrate the surface (s). Result of infiltration test for pervious concrete with sizes and types aggregate is shown in Table 5.

\subsection{Statistic hypotheses}

The hypotheses, $H_{0}: \mu_{0}=\mu_{1}$ and $H_{1}: \mu_{0} \neq \mu_{1}$, where, $\mu_{0}$ is compression strength of pervious concrete with pea gravel and various sizes aggregate and $\mu_{1}$ is compression 
TABLE 5: Result of infiltration test with various sizes and types aggregate and wcr.

\begin{tabular}{l|c|c|c|c|c|c|} 
Wcr & \multicolumn{2}{|c|}{ Natural aggregate (pea gravel) } & \multicolumn{3}{c}{ Crushed stone } \\
& $(19-12.5) \mathrm{mm}$ & $(12.5-9.5) \mathrm{mm}$ & $(9.5-4.75) \mathrm{mm}$ & $(19-12.5) \mathrm{mm}$ & $(12.5-9.5) \mathrm{mm}$ & $(9.5-4.75) \mathrm{mm}$ \\
\hline 0.27 & 23.76 & 19.82 & 14.25 & 23.45 & 17.10 & 11.98 \\
\hline 0.30 & 22.69 & 20.26 & 15.18 & 18.30 & 18.57 & 14.13 \\
\hline 0.34 & 20.94 & 20.39 & 11.62 & 18.59 & 17.62 & 13.02
\end{tabular}

strength of pervious concrete with crushed stone and various sizes aggregate. The compression strength data results before further analysis is carried out by testing the requirements analysis including randomness test, homogeneity or uniformity and normality of the results data. The randomness was felt fulfilled by randomly taking 6 test results for 10 specimens. For compressive strength test at 3-days data is converted to 28-days [44, 45] similar proposed by $\mathrm{ACl}$ committee [46], expression as $f_{C, D}^{\prime}=$ $\left[(D /(D+q)] p\right.$, where, $f_{C, D}^{\prime}$ is strength of the concrete at Dth day ( $\left.\mathrm{D}=1,2,3, \ldots ..\right) ; D$ is numbers of days; $p$ and $q$ are constants for each curve but different for different data sets (curves). The values of $p=29.35$ and $q=3.730$ with coefficient of correlation 0.995. Then the results of the compressive strength and infiltration tests were tested for normality and uniformity by using one-sample Kosmogorov-Smirnov. The results of the uniformity and normality test using SPSS application. So the data can be further analyzed.

\section{Results}

\subsection{Effect of aggregate properties}

Based on Table 4, the unit weight (density) and void in mixture of the pervious concrete using natural aggregates (pea gravel) and crushed stone, indicating that the larger sizes of coarse aggregate ( $19 \mathrm{~mm}-12.5 \mathrm{~mm}$ ) will be increased void in mixture and decreased a density in shown in Figure 4 (a). The smaller sizes of aggregate $(9.5 \mathrm{~mm}-4.75 \mathrm{~mm})$ will be increased unit weight of pervious concrete and decreased void in mixture as shown in Figure 4 (b). The compressive strength at the age of 3-days, the average test results showed that with the increase of the cement water ratio in the pervious concrete mixture using natural aggregate and crushed stone showed a slightly difference with a compressive strength increase of about $10 \%$. Increasing the size of the aggregate will reduce the compressive strength of the concrete. Optimal concrete compressive strength is achieved by using a $12.5 \mathrm{~mm}$ aggregate that passes and is retained at 9.5 
mm, as shown in Figure 5 (a). The same thing is shown in Figure 5 (b) for the compressive strength for 28-days.
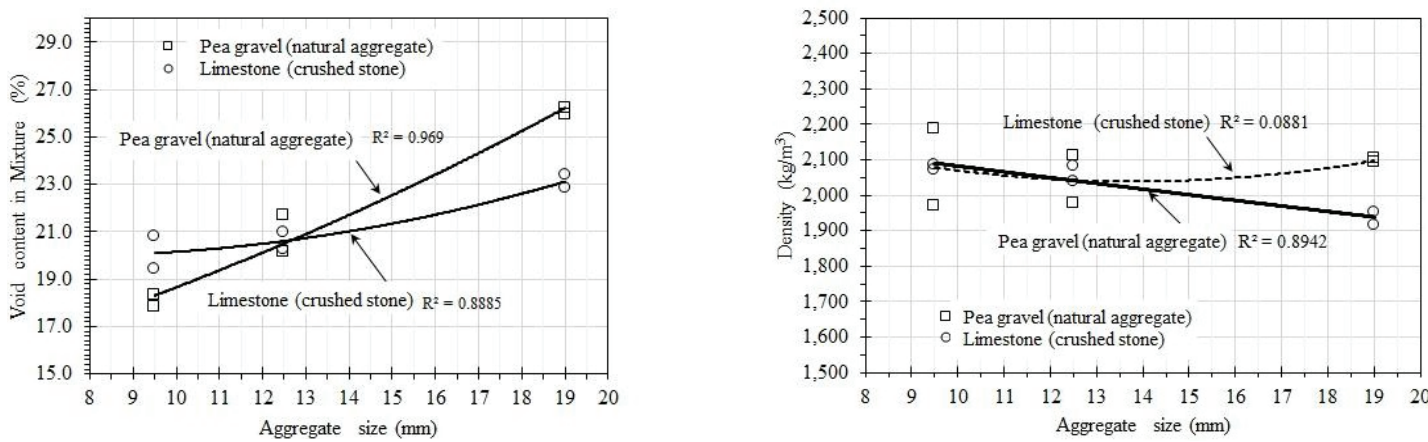

Figure 4: Pervious concrete with various sizes and types aggregate, void in mixture (a), density (b).
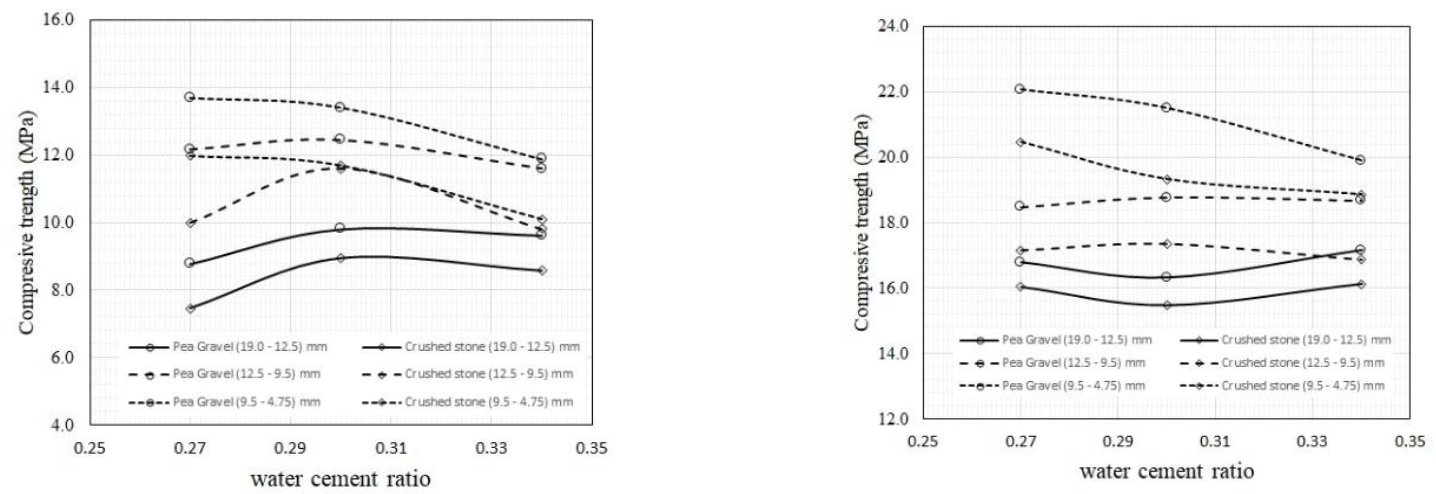

Figure 5: Compressive strength with various sizes and types aggregate, 3-days (a), 28-days (b).
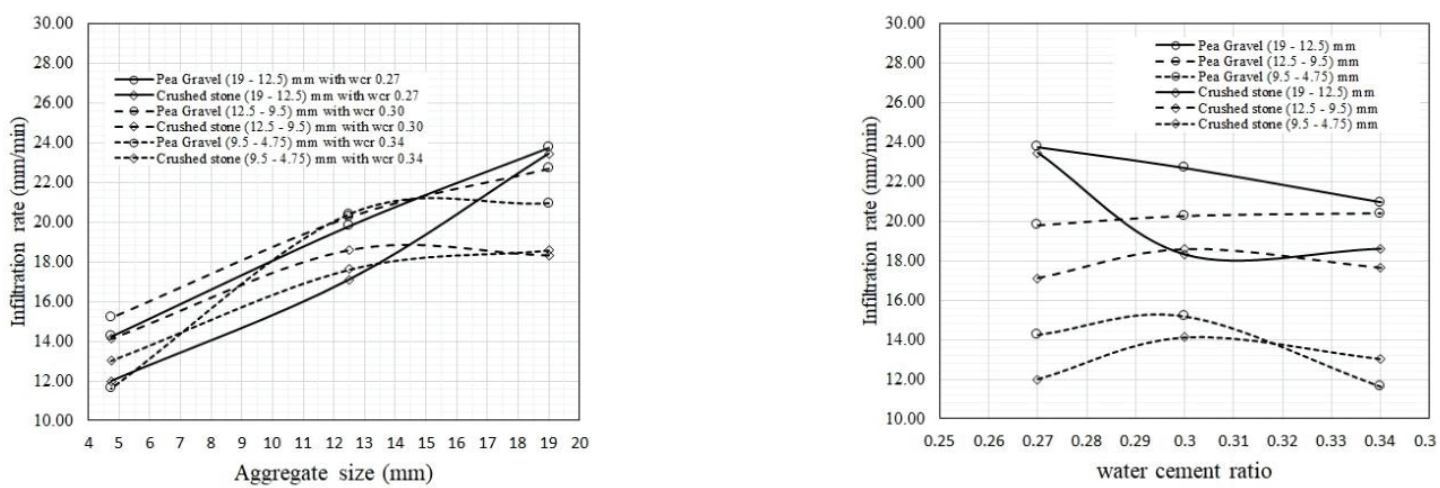

Figure 6: Infiltration rate with various aggregates (a), various water cemen ratio (b).

\subsection{Effect of aggregates size and wcr on void in mixed}

Based on the results of the infiltration test (Table 6), small aggregates will provide void in mixed for pervious concrete mixtures, so that the rate of infiltration in pervious 
concrete using sizes aggregate passed $9.5 \mathrm{~mm}$ and retained $4.75 \mathrm{~mm}$ sieves will be produces a lower infiltration rate than concrete using aggregates passed $19 \mathrm{~mm}$ sieve and retained $12.5 \mathrm{~mm}$. The greater the aggregate size will be increased the void in the mixture and increase the rate of infiltration, as shown in Figure 6 (a). The use of different water cement ratio, as shown in Figure 6 (b), thats the optimum infiltration rate obtained around wcr 0.3 for sizes and types aggregate.

\subsection{Proof of hypothesis}

Using the data of the compressive strength test from Table 5, T-test paired was carried out. Based on the results of paired T-tests, which are used to test hypotheses. The SPSS output shows that the

compressive strength for pervious concrete between used of natural aggregate (pea gravel) and crushed stone (limestone) does not have a significant difference. Thus, it was stated that the $H 1$ hypothesis is rejected.

\section{Discussion}

The results of the tests showed that a highest water-cement ratio would produce a low compressive strength in accordance from [25] and this result was not clearly shown in this study for the difference in wcr range 0.27 to 0.34 because it uses added admixture with a low proportion of $0,2 \%$ of the weight of cement. The difference can be seen clearly when using admixture as a superplastisizer (SP) which is close to the maximum number. The use of SP will increase the workability to highest consistency with the equal compressive strength. The infiltration rate results with wcr variations showed a large difference and the use of natural aggregates compared with crushed rocks in this study was small. The use of different compaction methods will produce vacancies in different mixtures according to the results of the research conducted, by [35]. Implementation in the field generally uses roller compaction, in this test uses a combination of drop hammer and tamping rod. For flexure strength in this research was not carried out. To estimate flexure strength can use empirical equations based on the value of the compressive test, using $f_{r}=0.62 \sqrt{f^{\prime}}$, as found in the standard [41, 42]. The highest of compressive strength, accordingly the flexural strength is highest. 


\section{Conclusion}

The results of the study on the effect of sizes and types aggregate on different water cement ratio in pervious concrete mixes cannot be clearly demonstrated, because of differences in the use of water cement ratio in the mixture 0.27 to 0.34 . Therefore, it is necessary to make a greater difference in the water cement ratio or if using the water cement ratio in the same range the use of chemical additives with levels that are close to the maximum according to the manufacturer's recommendations will be able to produce highest compressive strength and flexural strength. Optimization of the proportion of the correct sizes aggregate proposed in this study was to used wcr 0.3 and aggregate that passed through a $12.5 \mathrm{~mm}$ sieve, that was retained at $9.5 \mathrm{~mm}$ and that provided compressive strength are 8-14 MPa for 3-days and (15-22) MPa at 28-days. This is meets the strength requirements for local roads with compressive strength range 15 $\left.\leq f^{\prime}<20\right) \mathrm{MPa}$ [5]. The resulting density is between $(2.0-2.15) \mathrm{kg} / \mathrm{m}^{3}$ with void in the mixture at intervals of $20-22 \%$. The resulting infiltration rate is $(17-21) \mathrm{mm} / \mathrm{min}$.

\section{Funding}

This research work was supported by the Research grant from Jakarta State University.

\section{Acknowledgement}

The authors would like to thank their colleague for their contribution and support to the research. They are also thankful to the technicians of the Material Testing Laboratory on Civil Engineering Program, Engineering Faculty, State University of Jakarta and to all the reviewers who gave their valuable inputs to the manuscript and helped in completing the paper.

\section{Conflict of Interest}

The authors have no conflict of interest to declare.

\section{References}

[1] Sauquet, E., \& Lang, M. (2017). Flood Regimes: Recent Development and Future under Climate Change. In Floods, pp. 299-309. London, UK: ISTE Press - Elsevier. 
https://doi.org/https://doi.org/10.1016/B978-1-78548-268-7.50018-3

[2] PT Holcim Indonesia Tbk. (2015). Sustainable Development Report 2015. Jakarta: PT Holcim Indonesia

[3] Law Number. 38 of 2004 on Road. Republic of Indonesia.

[4] Nguyen, D. H., Sebaibi, N., Boutouil, M., et al. (2014). A modified method for the design of pervious concrete mix. Construction and Building Materials, vol. 73, pp. 271-282. https://doi.org/10.1016/j.conbuildmat.2014.09.088

[5] Direktorat Jenderal Bina Marga - Kementerian Pekerjaan Umum. (2015). Dokumen Pengadaan Pekerjaan Fisik dan Spesifikasi Umum 2010 (Revisi 2) untuk Pekerjaan Konstruksi (Pemborongan) Jalan dan Jembatan). Jakarta: Kementerian Pekerjaan Umum.

[6] Wanielista, M., Chopra, M., Spence, J., \& Ballock, C. (2007). Hydraulic performance assessment of pervious concrete pavements for stormwater management credit, (Final Report). Stormwater Management Academy - University of Central Florida.

[7] Obla, K. H. (2007). Pervious Concrete for Sustainable Development. Recent Advances in Concrete Technology, vol. September, pp. 151-174. Retrieved from http://www.nrmca.org/research/pervious recent advances in concrete technology0707.pdf

[8] Obla, K. H. (2010). Pervious concrete - An overview. The Indlan Concrete Journal, vol. August 2010, pp. 9-18. https://doi.org/10.1201/b18613-8

[9] ACl Commitee 522. (2010). Report on Pervious Concrete. Farmington Hills, Ml: American Concrete Institute. Retrieved from https://www.concrete.org/Portals/0/ Files/PDF/Previews/522R-10web.pdf

[10] Smith, K. D., \& Krstulovich, J. (2012). TechBrief: Pervious Concrete (FHWA-HIF13-006). Federal Highway Administration (FHWA) and The Advanced Concrete Pavement Technology (ACPT). Retrieved from http://www.fhwa.dot.gov/pavement/ concrete

[11] Tennis, P. D., Leming, M. L., \& Akers, D. J. (2004). Pervious Concrete Pavements, (EB302.02). USA: Portland Cement Association, Skokie, Illinois, and National Ready Mixed Concrete Association, Silver Spring, Maryland. Retrieved from http://myscmap. sc.gov/marine/NERR/pdf/PerviousConcrete_pavements.pdf

[12] Nassiri, S., \& Alshareedah, O. (2017). Preliminary Procedure for Structural Design of Pervious Concrete Pavements (Report No. WA-RD 868.2 2). Department of Civil and Environmental Engineering, Washington State University - U.S. Department of Transportation, Federal Highway Administration, Washington, DC. 
[13] Kuosa, H., Niemeläinen, E., \& Korkealaakso, J. (2014). Pervious pavement testing methods. State-of-the-Art and laboratory and field guideline for performance assessment (Research Report VTT-R-08225-13). Espoo, Finland.

[14] Barišić, I., Galić, M., \& Grubeša, I. N. (2017). Pervious concrete mix optimization for sustainable pavement solution. In IOP Conference Series: Earth and Environmental Science (pp. 0-6). IOP Publishing Ltd. https://doi.org/10.1088/1755-1315/90/1/012091

[15] Marks, A. (2008). Pervious Concrete Pavement. Journal of Green Building, vol.3(3), pp.36-41. https://doi.org/10.3992/jgb.3.3.36

[16] Neithalath, N., Bentz, D., \& Sumanasoorlya, M. (2010). Predicting the Permeability of Pervious Concrete: Advances in Characterization of Pore Structure and Transport Properties. Concrete International, vol. 32(5), pp. 35-40. Retrieved from http://trid. trb.org/view.aspx?id=917916

[17] NZRMCA (2012). Pervious Concrete (Technical Note 9). New Zealand.

[18] Nassiri, S., Rangelov, M., \& Chen, Z. (2017). Preliminary Study to Develop Standard Acceptance Tests for Pervious Concrete (Report No. WA-RD 868.1). Department of Civil and Environmental Engineering, Washington State University - U.S. Department of Transportation, Federal Highway Administration, Washington, DC.

[19] Kevern, J. T. (2015). Evaluating Permeability and Infiltration Requirements for Pervious Concrete. Journal of Testing and Evaluation, vol. 43(3), pp. 544-553. https://doi.org/10.1520/JTE20130180

[20] Schaefer, V. R., Kevern, J. T., \& Wang, K. (2011). An Integrated Study of Pervious Concrete Mixture Design for Wearing Course Applications (Report No. DTFH61-06H-00011 Work Plan 10). National Concrete Pavement Technology Center lowa State University, Ames, IA 50010- 8664. Retrieved from http://www.cptechcenter.org

[21] Joshi, T., \& Dave, U. (2016). Evaluation of strength, permeability and void ratio of pervious concrete with changing $\mathrm{W} / \mathrm{C}$ ratio and aggregate size. International Journal of Civil Engineering and Technology, vol. 7(4), pp.276-284.

[22] ACl Committee 522. (2013). Specification for Pervious Concrete Pavement an ACl Standard. Farmington Hills, MI: American Concrete Institute.

[23] NRCA. (2004). Concrete in Practice. What, why and how? (CIP 38 - Pervious Concrete). Retrieved from http://www.nrmca.org/aboutconcrete/cips/38p.pdf

[24] Schaefer, V. R., Wang, K., Suleiman, M.., \& Kevern, J. T. (2006). Mix design development for pervious concrete in cold weather climates (Report No. 200601). Center for Transportation Research and Education, lowa State University - the National Concrete Pavement Technology Center, Ames, IA 50010-8634. Retrieved from http://www.ctre.iastate.edu/reports/mix_design_pervious.pdf 
[25] Kovac, M., \& Sicakova, A. (2017). Changes of strength characteristics of pervious concrete due to variations in water to cement ratio, In 1st International Conference on Advances in Environmental Engineering (AEE 2017) - IOP Conference Series: Earth and Environmental Science 92 (2017) 012029, vol. 92(1). United Kingdom: IOP Publishing. https://doi.org/10.1088/1755-1315/92/1/012029

[26] Schlumpf, J., Bicher, B., \& Schwoon, O. (2005). Sika ${ }^{\circledR}$ Concrete Handbook. Zürich: Sika AG.

[27] Thomas, M. D. A. (2007). Optimizing the Use of Fly Ash, in Concrete, pp.124. Skokie, Illinois 60077-1083 USA: Portland Cement Association. Retrieved from https://www.cement.org/docs/default-source/fc_concrete_technology/is548optimizing-the-use-of-fly-ash-concrete.pdf

[28] COIN Project report 18. (2010). Fly ash in concrete A literature study of the advantages and disadvantages. Blindern - Norwegian: SINTEF Building and Infrastructure.

[29] SNI 7064:2014. (2014). Semen portland komposit. Jakarta: National Standardization Agency of Indonesia.

[30] Zheng, M., Chen, S., \& Wang, B. (2012). Mix design method for permeable base of porous concrete. International Journal of Pavement Research and Technology, vol. 5(2), pp. 102-107.

[31] ASTM C33/C33M-18. (2018). Standard Specification for Concrete Aggregates. West Conshohocken, PA: ASTM International. https://doi.org/10.1520/C0033_C0033M-18

[32] SNI 8321:2016. (2016). Spesifikasi agregat beton (ASTM C33/C33M - 13, IDT Standard Specification for Concrete Aggregates). Jakarta: National Standardization Agency of Indonesia. Retrieved from Spesifikasi agregat beton (ASTM C33/C33M - 13, IDT)

[33] SNI 2460:2014. (2014). Standard specification for coal fly ash and raw or calcined natural pozolan for use in concrete (ASTM C618-08a, IDT). Jakarta: National Standardization Agency of Indonesia.

[34] SNI 7974:2013. (2013). Standard specification for mixing water used in the production of hydraulic cement concrete. Jakarta: National Standardization Agency of Indonesia.

[35] Lian, C., \& Zhuge, Y. (2010). Optimum mix design of enhanced permeable concrete - An experimental investigation. Construction and Building Materials, vol. 24(12), pp. 2664-2671. https://doi.org/10.1016/j.conbuildmat.2010.04.057

[36] ASTM C192/C192M - 14. (2014). Standard Practice for Making and Curing Concrete Test Specimens in the Laboratory. West Conshohocken, PA: ASTM International. https://doi.org/10.1520/C0192_C0192M-14 
[37] ASTM C1688/C1688M-14a, \& ASTM C1688. (2014). Standard Test Method for Density and Void Content of Freshly Mixed Pervious Concrete. West Conshohocken: ASTM International. https://doi.org/10.1520/C1688_C1688M-14A

[38] SNI 2493:2011. (2011). Tata cara pembuatan dan perawatan benda uji beton di laboratorium. Jakarta: National Standardization Agency of Indonesia.

[39] SNI 1974:2011. (2011). Cara uji kuat tekan beton dengan benda uji silinder. Badan Standardisasi Nasional. Jakarta: National Standardization Agency of Indonesia.

[40] ASTM C39/C39M-18. (2018). Standard Test Method for Compressive Strength of Cylindrical Concrete Specimens. West Conshohocken, PA: ASTM International. https://doi.org/10.1520/C0039_C0039M-18

[41] ACl Committee 318. (2014). Building Code Requirements for Structural Concrete (ACl 318M-11) An ACl Standard and Commentary. Farmington Hills, Ml: American Concrete Institute. https://doi.org/10.1016/0262-5075(85)90032-6

[42] SNI 2847:2013. (2013). Persyaratan beton struktural untuk bangunan gedung. Jakarta: National Standardization Agency of Indonesia.

[43] ASTM C1701/C1701M-17a. (2017). Standard test Method for infiltration rate of in place pervious concrete. West Conshohocken, PA: ASTM International. https://doi.org/10. 1520/C1701_C1701M-17A

[44] Hasan, M., \& Kabir, A. (2013). Early Age Tests to Predict 28 Days Compressive Strength of Concrete, Caspian Journal of Applied Sciences Research, vol.2 (in Proceeding of AWAM International Conference on Civil Engineering \& Geohazard Information Zonation, 2012), pp. 234-241.

[45] Kabir, A., Hasan, M., \& Miah, K. (2012). Predicting 28 Days Compressive Strength of Concrete from 7 Days Test Result, in Proceedings of International Conference on Advances in Design and Construction of Structures . Bangalore, India: The Institute of Doctors Engineers and Scientists (IDES), pp. 18-22. https://doi.org/02.ADCS.2012. 1. 505

[46] ACl 209R-92. (1997). Prediction of Creep, Shrinkage and Temperature Effects in Concrete Structures. Farmington Hills, MI: American Concrete Institute. https://doi. org/10.1201/9780203882955.ch168 